\title{
NITROGEN AND PHOSPHOROUS REMOVAL OF PILOT-SCALE ANAEROBIC-ANOXIC-AEROBIC PROCESS UNDER PLATEAU ENVIRONMENTAL FACTORS
}

\author{
ZONG, Y. C. ${ }^{1,2,3,4,5,6}-$ HAO, K. Y. ${ }^{6}-$ LI, Y. W. ${ }^{6}-$ LU, G. H. ${ }^{1,2,3,4,5,6^{*}}-$ HUANG, D. C. ${ }^{6}$ \\ ${ }^{I}$ Res. Institute of Tibet Plateau Ecology, Tibet Agriculture \& Animal Husbandry University \\ Linzhi 860000, China \\ ${ }^{2}$ Tibet Key Laboratory of Forest Ecology in Plateau Area, Ministry of Education \\ Linzhi 860000, China \\ ${ }^{3}$ National Key Station of Field Scientific Observation \& Experiment, Linzhi 860000, China \\ ${ }^{4}$ Key Laboratory of Forest Ecology in Plateau Area, Tibet Autonomous Region \\ Linzhi 860000, China \\ ${ }^{5}$ United Key Laboratories of Ecological Security, Tibet Autonomous Region \\ Linzhi 860000, China \\ ${ }^{6}$ Water Conservancy Project \& Civil Engineering College, Tibet Agriculture \& Animal \\ Husbandry University, Linzhi 860000, China \\ (phone: +86-13062577435) \\ * Corresponding author \\ e-mail: ghlu@hhu.edu.cn; phone: +86-13062577435 \\ (Received $3^{\text {rd }}$ May 2019; accepted $11^{\text {th }}$ Jul 2019)
}

\begin{abstract}
Considering the two unique factors of the plateau environment (i.e. water temperature and oxygen partial pressure), this paper explores the nitrogen and phosphorous removal of pilot-scale anaerobic-anoxic-aerobic (A2O) process. The experimental results show that none of the total phosphorous (TP), total nitrogen (TN) or $\mathrm{NH}_{4}{ }^{+} \mathrm{N}$ of the outlet water satisfied the Chinese national standard GB18918-2002, while COD only fulfilled the standard requirements under a few working parameters. The optimal values of the four working parameters were determined as: the optimal $\mathrm{HRT}=26.25 \mathrm{~h}$, the optimal $\mathrm{DO}=3.0 \mathrm{mg} / \mathrm{L}$, the optimal temperature $=15^{\circ} \mathrm{C}$. All these optimal values deviated greatly from the existing studies. The microbial densities corresponded poorly to the three working parameters, and were smaller than those under non-plateau environment; the number of indicator microorganisms had good correspondence with the optimal values of our experimental parameters.

Keywords: anaerobic-anoxic-aerobic (A2O) process, water temperature, hydraulic retention time $(H R T)$, dissolved oxygen (DO), nitrogen and phosphorous removal
\end{abstract}

\section{Introduction}

The anaerobic-anoxic-aerobic (A2O) process, improved from the traditional activated-sludge process, has become the most popular sewage treatment method in Tibet (Chen et al., 2018), China. It is widely agreed that the effect of A2O is influenced by the unique environment factors of the plateau, namely, water temperature and pressure.

With a mean elevation of more than $4,000 \mathrm{~m}$, Tibet can be categorized as a typical plateau region with low temperature. Taking Linzhi for instance, the domestic sewage falls in the range of $4{ }^{\circ} \mathrm{C}$ and $14^{\circ} \mathrm{C}$ (Zong et al., 2018), which is a typical low- 
temperature sewage. The water temperature in other parts of Tibet is theoretically below this range, because Linzhi is a city with below-average elevation in Tibet.

According to Lewis-Whitman's two-film theory (Ruiz-Urbieta et al., 1975), the maximal concentration of oxygen that can be dissolved in liquid medium decreases with the pressure. The atmospheric pressure is only $67.24 \mathrm{kPa}$ in Linzhi. The elevation and atmospheric pressure of other cities in Tibet are listed in Table 1 below.

Table 1. Elevation, pressure of Tibet in China

\begin{tabular}{c|c|c|c|c|c|c|c}
\hline & Lhasa & Changdu & Shigatse & Linzhi & Shannan & Naqu & Ali \\
\hline Elevation $(\mathrm{m})$ & 3658.0 & 3306.0 & 3836.0 & 3000.0 & 3551.7 & 4507.0 & 4278.0 \\
The local pressure $(\mathrm{kPa})$ & 59.87 & 63.81 & 57.88 & 67.24 & 61.06 & 50.36 & 52.93 \\
Oxygen partial pressure (kPa) & 12.54 & 13.37 & 12.13 & 14.09 & 12.79 & 10.55 & 11.09 \\
Oxygen levels (\%) & 59.87 & 63.81 & 57.88 & 67.24 & 61.06 & 50.36 & 52.93 \\
\hline
\end{tabular}

Note: Standard Oxygen levels are 100\%

Temperature is a main influencing factor of sewage treatment (Ai et al., 2014; Abourabia and Abdel Moneim, 2019). Its influence mainly exists in the following aspects: On the phosphorus removal of sludge denitrification, the release and absorption rates of phosphorus are changed under excessively high or low temperatures, and the proportion of denitrifying phosphorus accumulating organisms (DPAOs) in the activated sludge is greatly affected by temperature variation (Zhang et al., 2016; Wu, 2017); the nitrification capacity of the sewage treatment system is obviously weakened when the water temperature falls below $15^{\circ} \mathrm{C}$, and basically disappears when the temperature drops below $4^{\circ} \mathrm{C}$ (He et al., 2010; Li et al., 2013). Thus, the nitrogen removal is severely inhibited under a low temperature (Li et al., 2014).

In view of the above, this paper explores the mechanism of nitrogen and phosphorus removal of A2O system, as a typical sewage treatment process. Starting from the microbial variation law, the author discussed the influence of water temperature, dissolved oxygen concentration, hydraulic retention time (HRT) and other factors on nitrogen and phosphorus removal, analyzed the operation features of $\mathrm{A} 2 \mathrm{O}$ system at high elevations, and investigated the microbial features in the anaerobic section, anoxic section and aerobic section. The research discloses the mechanism of nitrogen and phosphorus removal in the reactor, shedding light on how plateau environmental factors affect the mechanism of nitrogen and phosphorus removal. Moreover, our research results lay a theoretical basis for the biological sewage treatment system in the plateau environment.

\section{Materials and methods}

\section{Description of the A2O system and wastewater}

As mentioned above, our experiment aims to disclose the law of removal rates under different water temperatures, HRTs and dissolved oxygens (DOs). For this purpose, the process flow of our experiment was designed as the following chart.

A pilot-scale A2O sewage treatment device was designed and fabricated with plexiglass. With an effective volume of $210 \mathrm{~L}$, the device consists of 8 segments: the first 2 are anaerobic tanks, the middle 2 are anoxic tanks, and the last 4 are aerobic tanks. 
The volume ratio of the anaerobic, anoxic and aerobic sections is 1:1:2. Besides, the effective volume of the sedimentation tank is $26.25 \mathrm{~L}$. In both anaerobic and anoxic sections, each tank has a $50 \mathrm{rpm}$ stirring device at the bottom; in each aerobic tank, there is an aerator for oxygen supply. Inflow, return sludge and nitrifying liquid are controlled by a peristaltic pump. To maintain a constant temperature, the water temperature was regulated by a constant temperature circulator. In each tank, a sampling hole was opened on the tank wall. Before the experiment, the activated sludge was cured for $32 \mathrm{~d}$. The temperature, mixed liquor suspended solids (MLSS), and volume percent of MLSS after settling for 30 min $\left(\mathrm{SV}_{30}\right)$ were set to $22.5^{\circ} \mathrm{C}$, $4,787 \mathrm{mg} / \mathrm{L}$ and $35 \%$, respectively. The number of parallel samples per point is three, and the average of three samples is taken when the accuracy requirement is met, otherwise resampling is considered (Figure 1).

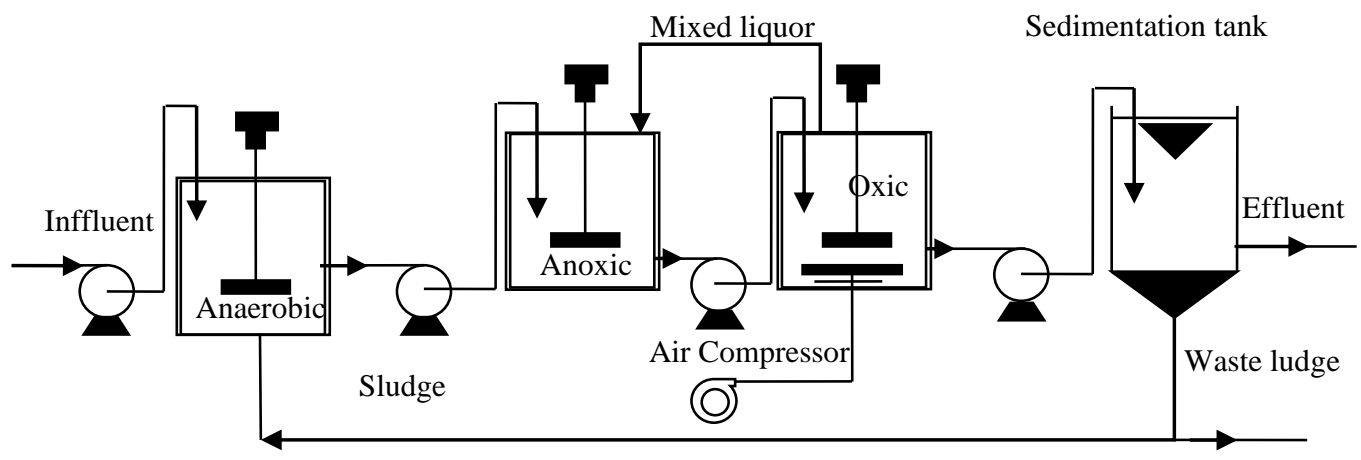

Figure 1. Schematic of anaerobic-anoxic-aerobic $(A 2 O)$ process

The urban domestic sewage in Linzhi was directly adopted for our experiments. The main water quality indices of the sewage are given in the table below (Table 2).

Table 2. Quality indicators of sewage

\begin{tabular}{c|c|c|c|c|c|c}
\hline $\mathbf{p H}$ & DO $(\mathbf{m g} / \mathbf{L})$ & Temperature $\left({ }^{\circ} \mathbf{C}\right)$ & $\mathbf{C O D}(\mathbf{m g} / \mathbf{L})$ & $\mathbf{T N}(\mathbf{m g} / \mathbf{L})$ & $\mathbf{T P}(\mathbf{m g} / \mathbf{L})$ & $\mathbf{N H}_{4}{ }^{+}-\mathbf{N}(\mathbf{m g} / \mathbf{L})$ \\
\hline $6.99 \sim 8.41$ & $1.12 \sim 5.08$ & $8.98 \sim 29.10$ & $149.48 \sim 526.36$ & $36.51 \sim 147.08$ & $3.96 \sim 11.56$ & $30.81 \sim 54.16$ \\
\hline
\end{tabular}

\section{Operation of the A2O device}

The operation of the $\mathrm{A} 2 \mathrm{O}$ device was studied under three working parameters, i.e. water temperature, hydraulic retention time (HRT) and DO, in order to disclose the law of removal rates under different water temperatures, HRTs and DOs. The control plans for the three parameters are specified below.

On water temperature control, the inlet water flow was designed as $10.0 \pm 0.1 \mathrm{~L} / \mathrm{s}$, HRT as $21.0 \pm 0.2 \mathrm{~h}$ (the HRT ratio between anaerobic tank, anoxic tank and aerobic tank=1: 1: 2), $\mathrm{DO}$ as $2.0 \pm 0.1 \mathrm{mg} / \mathrm{L}$, the reflux ratio of the mixed liquor $\mathrm{Ri}=200 \%$, and the reflux ratio of the sludge $\mathrm{R}=100 \%$. Both the mixed liquor and the sludge were continuously refluxed. The temperature was changed by an electric heater between five levels: $10,15,20,25$ and $30^{\circ} \mathrm{C}$. The water samples were collected $72 \mathrm{~h}$ after the temperature reached the design temperature. The temperature was controlled with an error of or less than $0.1^{\circ} \mathrm{C}$. 
On HRT control, the inlet water temperature was designed as $20 \pm 0.1{ }^{\circ} \mathrm{C}$, the HRT ratio between anaerobic tank, anoxic tank and aerobic tank as 1: 1: 2 , DO as $2.0 \pm 0.1 \mathrm{mg} / \mathrm{L}$, the reflux ratio of the mixed liquor $\mathrm{Ri}=200 \%$, and the reflux ratio of the sludge $\mathrm{R}=100 \%$. Both the mixed liquor and the sludge were continuously refluxed. HRT was adjusted by changing the inlet water flow between five levels: 4, 8, 12, 16 and $20 \mathrm{~L} / \mathrm{s}$. HRTs corresponding to the five levels were respectively $52.5,26.26,17.5$, 13.125 and $10.5 \mathrm{~h}$. The water samples were collected $72 \mathrm{~h}$ after the change of the inlet water flow. The flow was controlled with an error of or less than $\pm 0.1 \mathrm{~L} / \mathrm{s}$.

On DO control, the inlet water temperature was designed as $20 \pm 0.1^{\circ} \mathrm{C}$, the inlet water flow as $10.0 \pm 0.1 \mathrm{~L} / \mathrm{s}$, HRT as $21.0 \pm 0.2 \mathrm{~h}$ (HRT ratio between anaerobic tank, anoxic tank and aerobic tank=1:1:2), the reflux ratio of the mixed liquor $\mathrm{Ri}=200 \%$, and the reflux ratio of the sludge $\mathrm{R}=100 \%$. Both the mixed liquor and the sludge were continuously refluxed. DO was altered between 10 levels $(1,2,2.5,2.8,3,3.2,3.5,4$, 4.5 and $5 \mathrm{mg} / \mathrm{L}$ ) by changing the amount of blast aeration. The water samples were collected $72 \mathrm{~h}$ after DO reached the design level. DO was controlled with an error of or less than $\pm 0.1 \mathrm{mg} / \mathrm{L}$.

\section{Analytical methods}

According to the working standards, the experimental indices were respectively measured by the following methods: COD was determined by the potassium dichromate method, the TN by the ion chromatography, TP by potassium persulfate oxidation, MLSS by the gravimetric method, the SV30 by the standard method, DO by membrane electrode method, $\mathrm{pH}$ by the portable $\mathrm{pH}$ meter, $\mathrm{NH}_{4}{ }^{+}-\mathrm{N}$ by the Nessler's reagent photometry, the water temperature by water thermometer, the inlet water flow by float flowmeter, and the microorganisms by biochemical microscope counting.

\section{Results}

\section{Sewage treatment at different HRTs}

Table 3 displays the operation parameters like DO, MLSS, $\mathrm{pH}$ and temperature at different HRTs.

Table 3. Process Parameter at different hydraulic retention times (HRTs)

\begin{tabular}{c|c|c|c|c|c}
\hline Designed Flow (L/h) & $\mathbf{4}$ & $\mathbf{8}$ & $\mathbf{1 2}$ & $\mathbf{1 6}$ & $\mathbf{2 0}$ \\
\hline HRTs (h) & 52.50 & 26.25 & 17.50 & 13.13 & 10.50 \\
DO (mg/L) & 3.16 & 2.30 & 1.64 & 1.98 & 2.04 \\
$\mathrm{pH}$ & 8.10 & 8.00 & 8.27 & 8.40 & 8.41 \\
$\operatorname{MLSS}(\mathrm{mg} / \mathrm{L})$ & 964 & 996 & 1084 & 930 & 920 \\
$\operatorname{SV}_{30}(\%)$ & 10 & 10 & 10 & 10 & 10 \\
${\text { Temperature }\left({ }^{\circ} \mathrm{C}\right)}$ & 21.4 & 20.0 & 19.5 & 20.7 & 20.6 \\
\hline
\end{tabular}

\section{Effect on removal rates}

Figure 2 provides the removal rates of $\mathrm{COD}, \mathrm{TP}, \mathrm{TN}$ and $\mathrm{NH}_{4}{ }^{+}-\mathrm{N}$ in anaerobic, anoxic and aerobic tanks at different HRTs. 
As shown in Figure 2(a), the COD removal rate ranged between $69.65 \%$ and $93.98 \%$ under the five HRTs; in descending order of the COD removal rate, the inlet water flows were ranked as $8,12,16,4$ and $20 \mathrm{~L} / \mathrm{h}$, and HRTs as $26.25,17.50,13.13,52.50$ and $10.50 \mathrm{~h}$; the optimal HRT was much greater than $7 \sim 14 \mathrm{~h}$; the highest COD removal rate was observed at the design inlet water flow of $8 \mathrm{~L} / \mathrm{h}$; the removal effect was obvious in anaerobic and aerobic sections, but the removal rate was not significantly enhanced in the anoxic section.

As shown in Figure 2(b), the TP removal rates fell in the range of 4.53\% 64.56\% under the five HRTs; in descending order of TP removal rate, the inlet water flows were ranked as $8,12,20,16$ and $4 \mathrm{~L} / \mathrm{h}$, and HRTs as 26.25, 17.50, 10.50, 13.13 and $52.50 \mathrm{~h}$; the optimal HRT was much greater than $7 \sim 14 \mathrm{~h}$; the highest TP removal rate was observed at the design inlet water flow of $8 \mathrm{~L} / \mathrm{h}$; the removal effect was obvious in anaerobic and aerobic sections, but the removal rate was not significantly enhanced in the anoxic section.
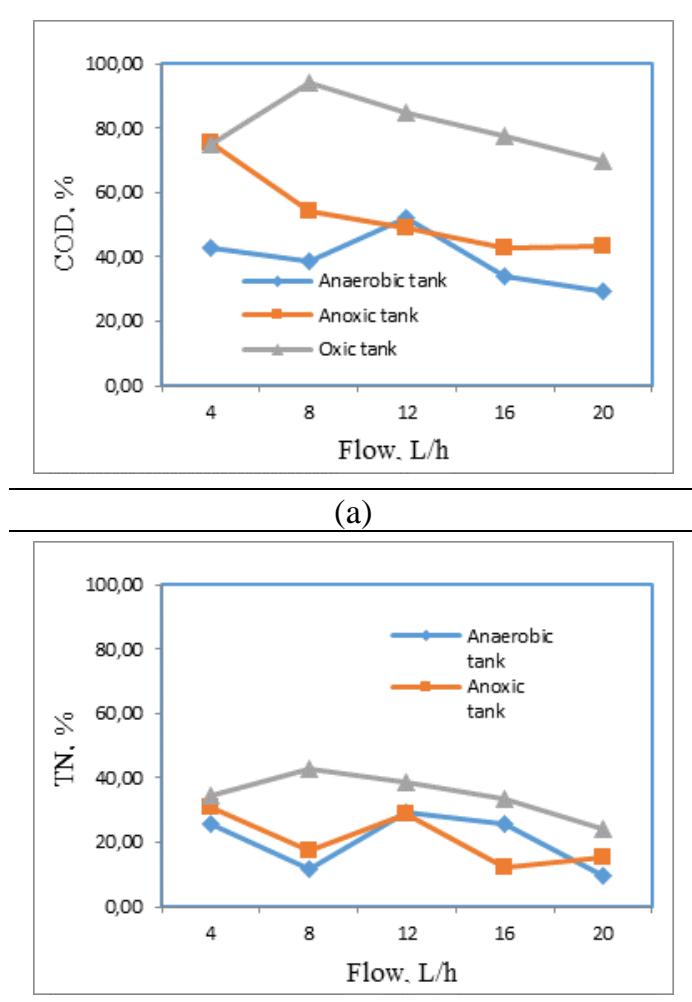

(c)

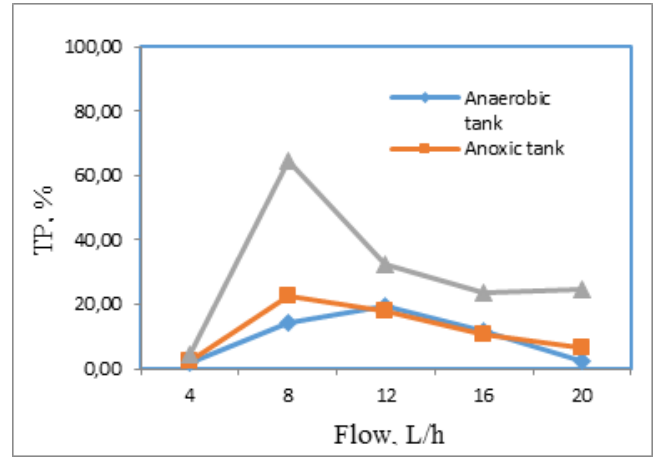

(b)

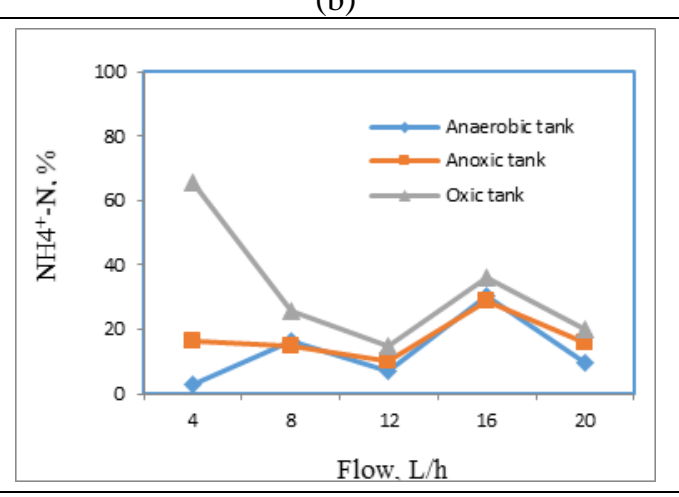

(d)

Figure 2. Removal rate at different hydraulic retention times (HRTs)

As shown in Figure 2(c), the TN removal rates shifted from $23.92 \%$ to $42.85 \%$ under the five HRTs; in descending order of the TN removal rate, the inlet water flows were ranked as 8, 12, 4, 16 and $20 \mathrm{~L} / \mathrm{h}$, and HRTs as 26.25, 17.50, 52.50, 13.13 and $10.50 \mathrm{~h}$; the optimal HRT was much greater than $7 \sim 14 \mathrm{~h}$; the highest TN removal rate was observed at the design inlet water flow of $8 \mathrm{~L} / \mathrm{h}$; the removal effect was obvious in anaerobic and aerobic sections, but the removal rate was not significantly enhanced in the anoxic section. 
As shown in Figure $2(d)$, the $\mathrm{NH}_{4}{ }^{+}-\mathrm{N}$ removal rates changed within $14.92 \%$ and $65.47 \%$; in descending order of the $\mathrm{NH}_{4}{ }^{+}-\mathrm{N}$ removal rate, the inlet water flows were ranked as $4,16,8,20,12 \mathrm{~L} / \mathrm{h}$, and the HRTs as $52.50,13.13,26.25,10.50$ and $17.50 \mathrm{~h}$; the optimal HRT was much greater than 7-14 h; the highest $\mathrm{NH}_{4}{ }^{+}-\mathrm{N}$ removal rate was observed at the design inlet water flow of $4 \mathrm{~L} / \mathrm{h}$; the removal effect was obvious in the aerobic sections, but the removal rate was not significantly enhanced in the anaerobic or anoxic section.

To sum up, the optimal HRT was $26.25 \mathrm{~h}$ among the five designed HRTs; HRT increased more significantly in the plateau environment than other regions.

\section{Microbial response}

The microbial density and indicator microorganisms under the above five HRTs are shown in Figure 3.

It can be seen from Figure 3(a) that, under the five HRTs, the different levels of inlet water flows could be ranked as $20,16,8,4$ and $12 \mathrm{~L} / \mathrm{h}$ in descending order of the number of microorganisms in the anaerobic section, 4, 16, 12, 20 and $8 \mathrm{~L} / \mathrm{h}$ in the anoxic section, and 20,4,12,16 and $8 \mathrm{~L} / \mathrm{h}$ in the aerobic section. Since the microbial effect is correlated with microbial density, microbial residence time, and inlet/outlet water quality, it is not reasonable to evaluate the microbial response with the bulk density of the microorganisms.

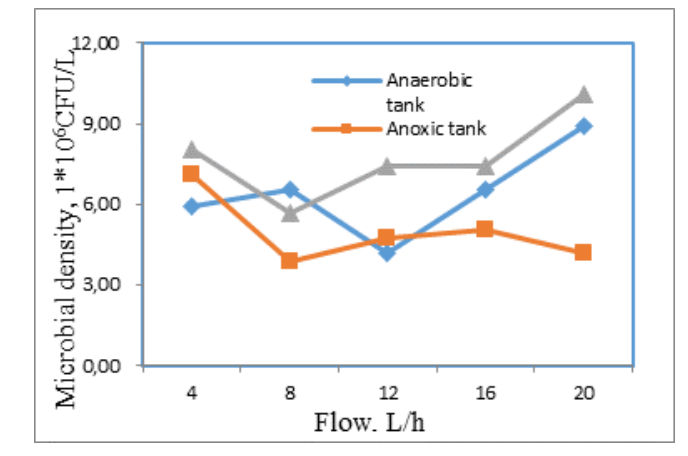

(a)

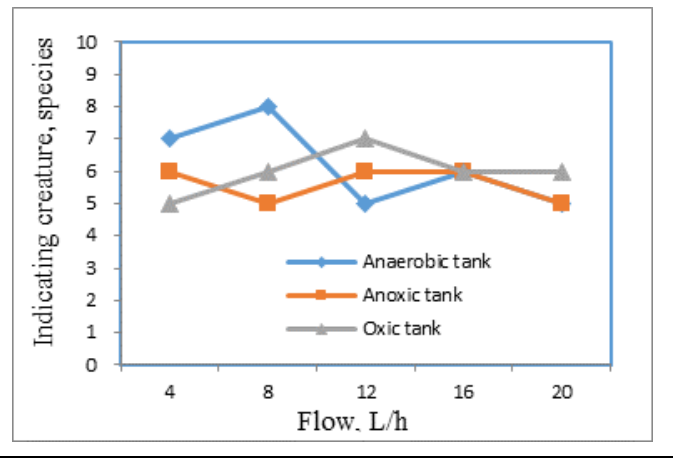

(b)

Figure 3. Microbial response at different hydraulic retention times (HRTs)

It can be seen from Figure 3(b) that, under the five HRTs, the different levels of inlet water flows could be ranked as $8,4,16,12$ and $20 \mathrm{~L} / \mathrm{h}$ in descending order of the diversity of indicator microorganisms in the anaerobic section, 16, 4, 12, 8 and $20 \mathrm{~L} / \mathrm{h}$ in the anoxic section, and $12,8,16,20$ and $4 \mathrm{~L} / \mathrm{h}$ in the aerobic section. The indicator microorganisms reached the peak diversity at $8 \mathrm{~L} / \mathrm{h}$. The most populous microorganisms include vorticella, trochilia, rotifera and oxytricha.

The microbial analysis show that the microbial density is not directly correlated with the optimal HRT, because the treatment effect depends on retention time and inlet/outlet water quality, in addition to microbial density; moreover, the indictor microorganism analysis confirmed that the indicator microorganisms reached the peak diversity at $8 \mathrm{~L} / \mathrm{h}$ and the most populous microorganisms were vorticella, trochilia, rotifera and oxytricha. 


\section{Sewage treatment at different $\mathrm{DO}$}

Table 4 lists the operation parameters like DO, MLSS, $\mathrm{pH}$ and temperature at different DOs.

Table 4. Process parameter at different dissolved oxygens (DOs)

\begin{tabular}{c|c|c|c|c|c|c|c|c|c|c}
\hline $\begin{array}{c}\text { Designed DO } \\
(\mathbf{m g} / \mathbf{L})\end{array}$ & $\mathbf{1 . 0}$ & $\mathbf{2 . 0}$ & $\mathbf{2 . 5}$ & $\mathbf{2 . 8}$ & $\mathbf{3 . 0}$ & $\mathbf{3 . 2}$ & $\mathbf{3 . 5}$ & $\mathbf{4 . 0}$ & $\mathbf{4 . 5}$ & $\mathbf{5 . 0}$ \\
\hline HRT $(\mathrm{h})$ & 26.25 & 26.25 & 26.25 & 26.25 & 26.25 & 26.25 & 26.25 & 26.25 & 26.25 & 26.25 \\
$\mathrm{DO}(\mathrm{mg} / \mathrm{L})$ & 1.12 & 2.01 & 2.42 & 2.82 & 2.92 & 3.20 & 3.54 & 3.90 & 4.50 & 5.08 \\
$\mathrm{pH}$ & 7.43 & 7.21 & 7.55 & 8.18 & 7.61 & 7.91 & 8.03 & 7.46 & 7.43 & 7.34 \\
MLSS (mg/L) & 247 & 568 & 714 & 928 & 1089 & 1043 & 1015 & 957 & 724 & 616 \\
$\mathrm{SV}_{30}(\%)$ & 8 & 9 & 10 & 10 & 10 & 10 & 10 & 10 & 9 & 8 \\
Temperature $\left({ }^{\circ} \mathrm{C}\right)$ & 20.10 & 21.00 & 18.80 & 20.00 & 18.70 & 20.00 & 20.40 & 19.70 & 19.80 & 20.80 \\
\hline
\end{tabular}

\section{Effect on removal rates}

Figure 4 gives the removal rates of $\mathrm{COD}, \mathrm{TP}, \mathrm{TN}$ and $\mathrm{NH}_{4}{ }^{+}-\mathrm{N}$ in anaerobic, anoxic and aerobic tanks at different DOs.
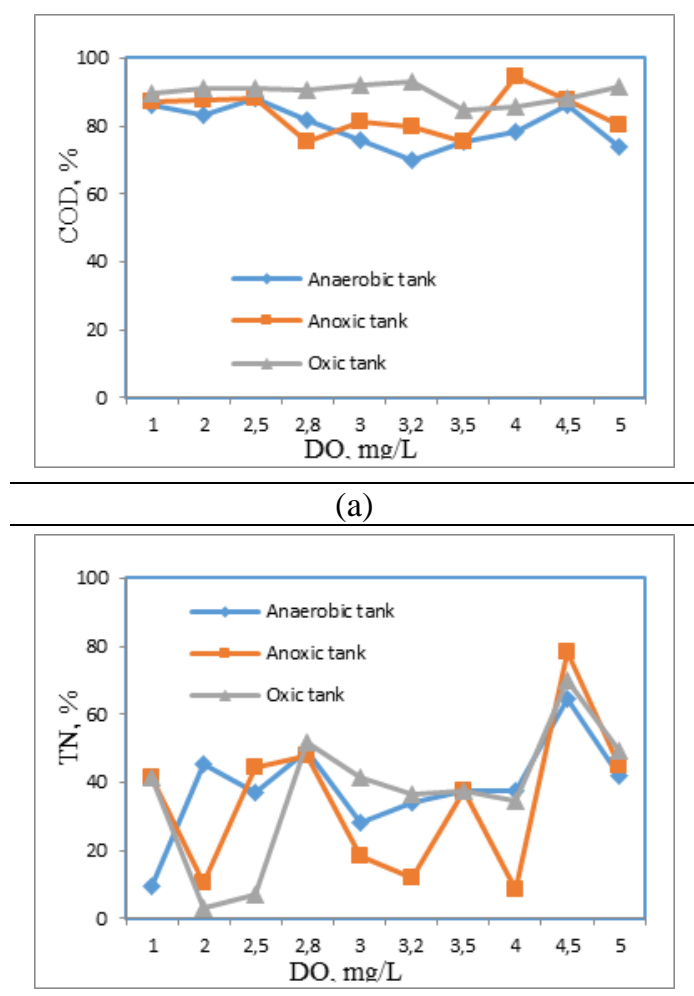

(c)

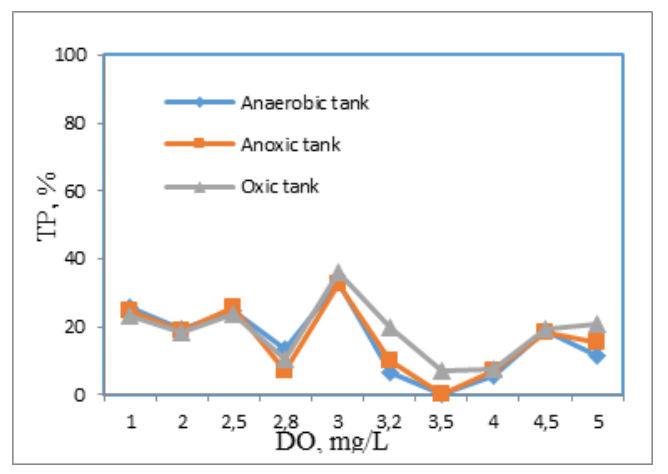

(b)

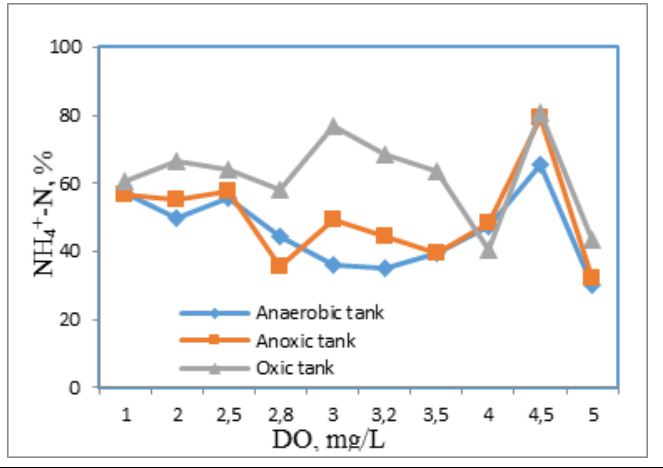

(d)

Figure 4. Removal rate at different dissolved oxygens (DOs)

As shown in Figure 4(a), the COD removal rate ranged between $84.59 \%$ and $92.84 \%$ under the ten DOs; in descending order of the COD removal rate, the DOs were ranked as 3.2, 3.0, 5.0, 2.5, 2.0, 2.8, 1.0, 4.5, 4.0 and $3.5 \mathrm{mg} / \mathrm{L}$; the optimal DO was far higher 
than $2.0 \mathrm{mg} / \mathrm{L}$, but the COD differed slightly between the working parameters; the COD removal rate peaked at the design DO of $3.2 \mathrm{mg} / \mathrm{L}$; the removal effect was obvious in anaerobic section, but the removal rate was not significantly enhanced in the anoxic or aerobic section.

As shown in Figure 4(b), the TP removal rate fluctuated between $7.27 \%$ and $35.84 \%$ under the ten DOs; in descending order of the TP removal rate, the DOs were ranked as $3,2,1,5,3.2,4.5,2,2.8,4$ and $3.5 \mathrm{mg} / \mathrm{L}$; the optimal DO was far higher than $2.0 \mathrm{mg} / \mathrm{L}$; the highest TP removal rate appeared at the design DO of $3 \mathrm{mg} / \mathrm{L}$; the removal effect was obvious in anaerobic section, but the removal rate was not increased in the anoxic or aerobic section.

As shown in Figure 4(c), the TN removal rate fell between $7.27 \%$ and $35.84 \%$ under the ten DOs; in descending order of the TN removal rate, the DOs were ranked as 3,2,1, $5,3.2,4.5,2,2.8,4$ and $3.5 \mathrm{mg} / \mathrm{L}$; the optimal DO was much higher than $2.0 \mathrm{mg} / \mathrm{L}$; the highest TN removal rate appeared at the design DO of $3 \mathrm{mg} / \mathrm{L}$; the removal effect was obvious in aerobic section, but the removal rate was not increased significantly in the anoxic or anaerobic section.

As shown in Figure $4(d)$, the $\mathrm{NH}_{4}{ }^{+}-\mathrm{N}$ removal rate changed between $80.76 \%$ and $40.35 \%$ under the ten DOs; in descending order of the $\mathrm{NH}_{4}{ }^{+}-\mathrm{N}$ removal rate, the DOs were ranked as 4.5, 3.0, 3.2, 2.0, 2.5, 3.5, 1.0, 2.8, 5.0 and $4.0 \mathrm{mg} / \mathrm{L}$; the optimal DO was much higher than $2.0 \mathrm{mg} / \mathrm{L}$; the $\mathrm{NH}_{4}{ }^{+}-\mathrm{N}$ removal rate reached the maximum at the design DO of $4.5 \mathrm{mg} / \mathrm{L}$; the removal effect was obvious in aerobic section, but the removal rate was not increased significantly in the anoxic or anaerobic section.

In summary, the optimal DO was $3 \mathrm{mg} / \mathrm{L}$ among the ten designed DOs; the DO in the plateau environment was much greater than that in the other regions; however, the removal rates of TP, TN and $\mathrm{NH}_{4}{ }^{+}-\mathrm{N}$ were not high under plateau environmental factors; in particular, only about $35 \%$ of TP were removed.

\section{Microbial response}

The microbial density and indicator microorganisms under the above seven DOs are displayed in Figure 5.

It can be seen from Figure 5(a) that the seven DOs could be ranked as 2.8, 4.5, 2.5, 5, 2, 3.2 and $1 \mathrm{mg} / \mathrm{L}$ in descending order of the number of microorganisms in the anaerobic section, 2.5, 5.0, 2.8, 3.2, 2, 4.5 and $1 \mathrm{mg} / \mathrm{L}$ in the anoxic section, and 2.5, 2.8, 5.0, 3.2, 4.5, 2 and $1 \mathrm{mg} / \mathrm{L}$ in the aerobic section. Since the microbial effect is correlated with microbial density, microbial residence time, and inlet/outlet water quality, it is not reasonable to evaluate the microbial response with the bulk density of the microorganisms.

It can be seen from Figure $5(b)$ that the seven DOs could be ranked as $2.8,4.5,1,2$, $2.5,5$ and $3.2 \mathrm{mg} / \mathrm{L}$ in descending order of the diversity of indicator microorganisms in the anaerobic section, 1, 5, 2.5, 3.2, 4.5, 2.8 and $2 \mathrm{mg} / \mathrm{L}$ in the anoxic section, and 5, 2, $2.5,3.2,1,2.8$ and $4.5 \mathrm{mg} / \mathrm{L}$ in the aerobic section. The indicator microorganisms reached the peak diversity at $5 \mathrm{mg} / \mathrm{L}$, when the most populous microorganisms were vorticella and rotifera. Meanwhile, the most populous microorganisms became vorticella, rotifera and trochilia at the DO of $3 \mathrm{mg} / \mathrm{L}$.

The microbial analysis show that the microbial density is not directly correlated with the optimal DO, because the treatment effect depends on retention time and inlet/outlet water quality, in addition to microbial density; moreover, the indictor microorganism 
analysis confirmed that the indicator microorganisms reached the peak diversity at $5 \mathrm{mg} / \mathrm{L}$, when the most populous microorganisms were vorticella and rotifera.

\section{Sewage treatment at different water temperatures}

Table 5 lists the operation parameters like DO, MLSS, pH and HRT at different water temperatures.

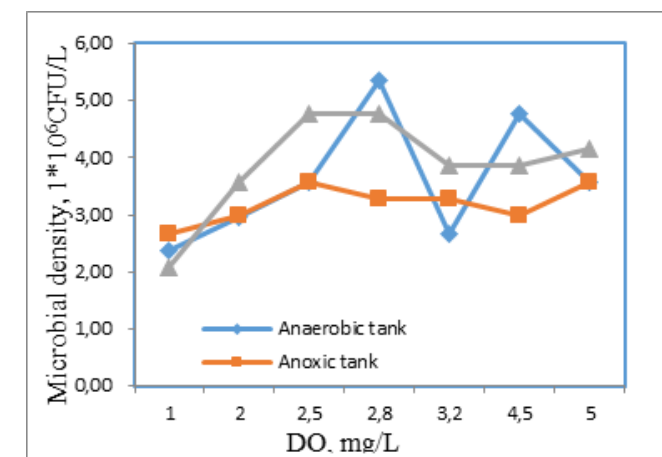

(a)

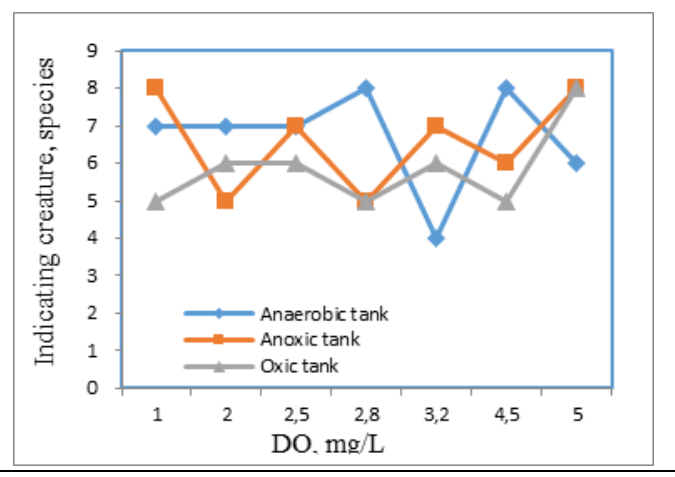

(b)

Figure 5. Microbial response at different dissolved oxygens (DOs)

Table 5. Process parameter at different temperatures

\begin{tabular}{c|c|c|c|c|c}
\hline Designed Temperature $\left({ }^{\circ} \mathbf{C}\right)$ & $\mathbf{1 0}$ & $\mathbf{1 5}$ & $\mathbf{2 0}$ & $\mathbf{2 5}$ & $\mathbf{3 0}$ \\
\hline $\mathrm{HRT}(\mathrm{h})$ & 26.25 & 26.25 & 26.25 & 26.25 & 26.25 \\
$\mathrm{DO}(\mathrm{mg} / \mathrm{L})$ & 1.80 & 1.87 & 1.76 & 1.80 & 1.63 \\
$\mathrm{pH}$ & 7.52 & 7.69 & 7.58 & 7.52 & 8.18 \\
$\mathrm{MLSS}(\mathrm{mg} / \mathrm{L})$ & 1137 & 2132 & 1889 & 1137 & 983 \\
$\mathrm{SV} 30(\%)$ & 15 & 17 & 15 & 15 & 13 \\
Temperature $\left({ }^{\circ} \mathrm{C}\right)$ & 8.98 & 14.8 & 17.5 & 22.4 & 29.1 \\
\hline
\end{tabular}

\section{Effect on removal rates}

Figure 6 shows the removal rates of COD, TP, TN and $\mathrm{NH}_{4}{ }^{+}-\mathrm{N}$ in anaerobic, anoxic and aerobic tanks at different water temperatures.

As shown in Figure 6(a), the COD removal rate ranged between $70.06 \%$ and $84.33 \%$ under the five water temperatures; in descending order of the COD removal rate, the water temperatures were ranked as $15,30,25,10$ and $20^{\circ} \mathrm{C}$; the optimal water temperature was obviously $15^{\circ} \mathrm{C}$, as the $\mathrm{COD}$ removal rate reached the peak value under this temperature; the removal effect was obvious in anaerobic section, but the removal rate was not significantly enhanced in the anoxic or aerobic section.

As shown in Figure 6(b), the TP removal rate fluctuated between $3.54 \%$ and $75.55 \%$ under the five water temperatures; in descending order of the TP removal rate, the water temperatures were ranked as $15,20,30,10$ and $25^{\circ} \mathrm{C}$; the optimal water temperature was obviously $15^{\circ} \mathrm{C}$, as the TP removal rate was the highest under this temperature; the removal effects were obvious in anaerobic and aerobic sections, but the removal rate was not significantly enhanced in the anoxic section. 
As shown in Figure 6(c), the TN removal rate fell between $36.60 \%$ and $77.98 \%$ under the ten DOs; in descending order of the TN removal rate, the water temperatures were ranked as $10,25,15,30$ and $20^{\circ} \mathrm{C}$; the optimal water temperatures were 10 and $25^{\circ} \mathrm{C}$, as the peak TN removal rate was measured under the two temperatures; the removal effects were obvious in anaerobic and aerobic sections, but the removal rate was not significantly enhanced in the anoxic section.
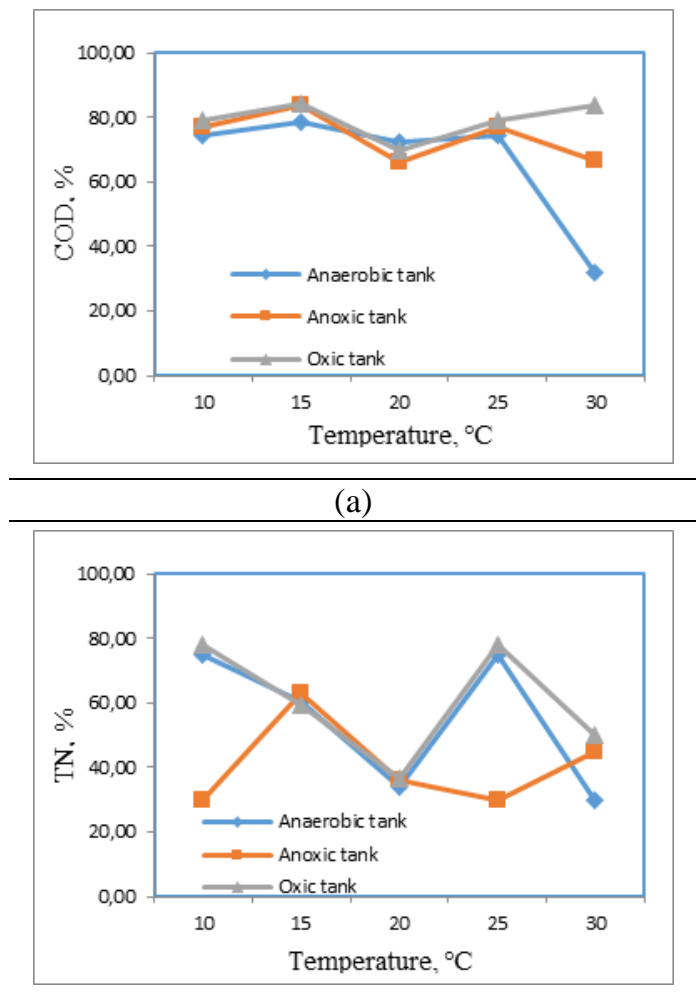

(c)

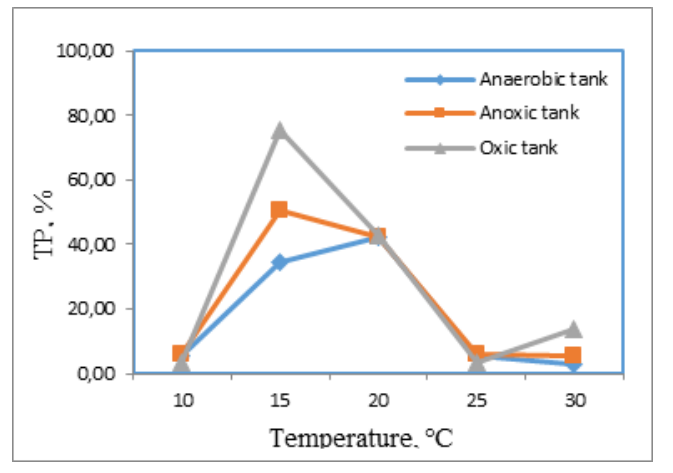

(b)

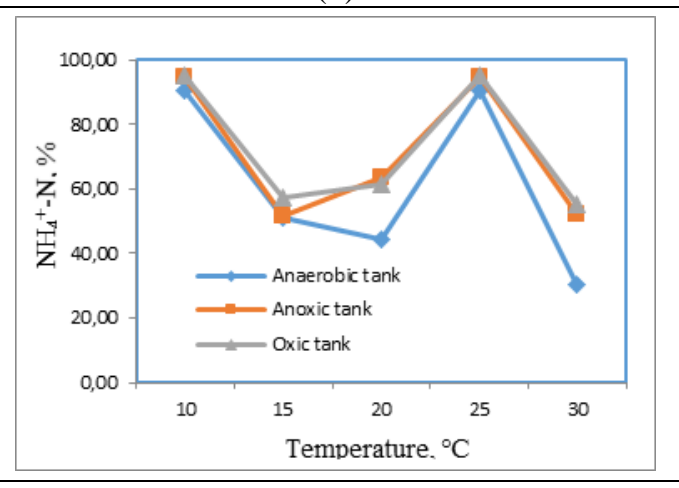

(d)

Figure 6. Removal rate at different temperatures

As shown in Figure $6(d)$, the $\mathrm{NH}_{4}{ }^{+}-\mathrm{N}$ removal rate changed between $55.44 \%$ and 95.44\% under the five water temperatures; in descending order of the $\mathrm{NH}_{4}{ }^{+}-\mathrm{N}$ removal rate, the water temperatures were ranked as $10,25,20,15$ and $30^{\circ} \mathrm{C}$; the optimal temperatures were 10 and $25^{\circ} \mathrm{C}$, as the peak $\mathrm{NH}_{4}{ }^{+}-\mathrm{N}$ removal rate was obtained under these two temperatures; the removal effect was obvious in anaerobic section, but the removal rate was not significantly enhanced in the anoxic or aerobic section.

Overall, the optimal water temperature was $15^{\circ} \mathrm{C}$ among the five designed water temperatures; the optimal temperature in the plateau environment was lower than that in the other regions.

\section{Microbial response}

The microbial density and indicator microorganisms under the above five water temperatures are displayed in Figure 7.

It can be seen from Figure 7(a) that the five water temperatures could be ranked as $20,15,10,25$ and $30^{\circ} \mathrm{C}$ in descending order of the number of microorganisms in the anaerobic section, $30,25,10,20$ and $15^{\circ} \mathrm{C}$ in the anoxic section, and 15, 30, 25, 10 and 
$20^{\circ} \mathrm{C}$ in the aerobic section. Since the microbial effect is correlated with microbial density, microbial residence time, and inlet/outlet water quality, it is not reasonable to evaluate the microbial response with the bulk density of the microorganisms.

It can be seen from Figure 7(b) that the five water temperatures could be ranked as $20,10,25,15$ and $30^{\circ} \mathrm{C}$ in descending order of the diversity of indicator microorganisms in the anaerobic section, $20,10,25,15$ and $30^{\circ} \mathrm{C}$ in the anoxic section, and $15,30,10,25$ and $20^{\circ} \mathrm{C}$ in the aerobic section. The indicator microorganisms reached the peak diversity at the water temperature of $20^{\circ} \mathrm{C}$, when the most populous microorganisms were vorticella, trochilia and oxytricha. Meanwhile, the most populous microorganisms were also vorticella, trotifera and trochilia at the water temperature of $15^{\circ} \mathrm{C}$.

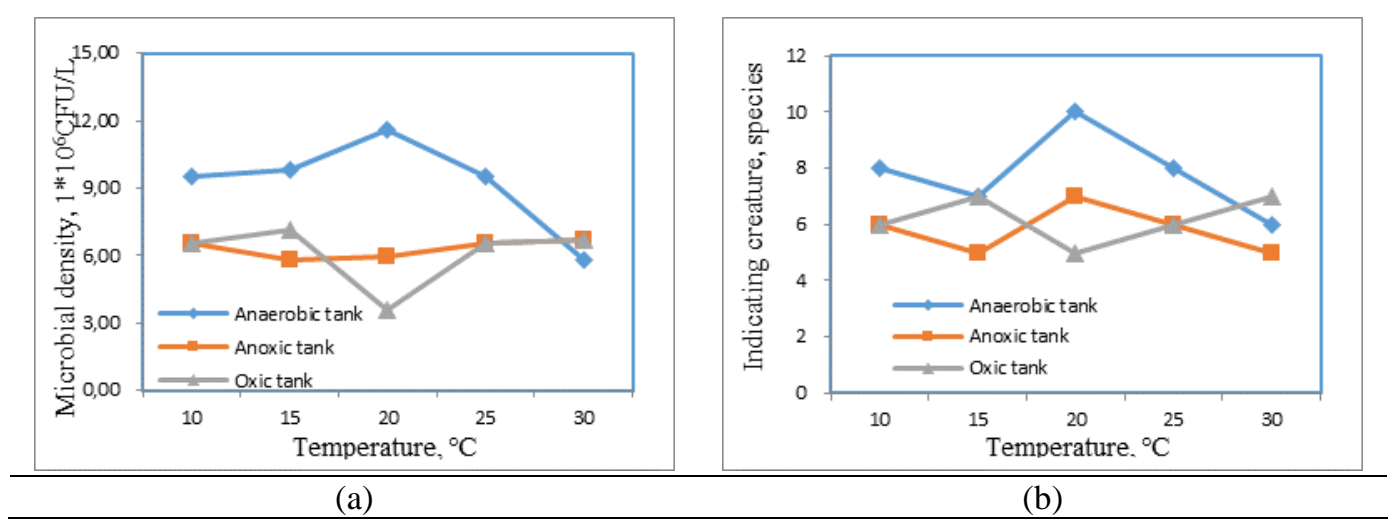

Figure 7. Microbial response at different temperatures

The microbial analysis show that the microbial density is not directly correlated with the optimal water temperature, because the treatment effect depends on retention time and inlet/outlet water quality, in addition to microbial density; moreover, the indictor microorganism analysis found that the indicator microorganisms reached the peak diversity at $15^{\circ} \mathrm{C}$, when the most populous microorganisms were vorticella, rotifera and oxytricha; furthermore, it should be noted that the diversity did not increase with the water temperature (Tian et al., 2013).

\section{Discussion}

\section{Discussion of HRTs}

Some of the recent studies on the optimal HRT are as follows. Wang et al. (2014) suggested that the optimal HRT was $8 \sim 12 \mathrm{~h}$ for the processing of high-load sewage by A2O and electro-coagulation. Ye et al. (2018) put the optimal HRT to $6 \mathrm{~h}$ for the removal of organic matters and nutrients from urban sewage with dual-A2O (D-A2O).

In our experiment, the optimal HRT is determined as $26.25 \mathrm{~h}$ based on the removal rates and microorganism response. This conclusion differs greatly from the results of the previous studies. The difference may be attributed to the environmental factor of low water temperature. The microbial density in low-temperature water body treated by the $\mathrm{A} 2 \mathrm{O}$ is generally considered as $10^{8} \mathrm{CFU} / \mathrm{L}$ (Yang, 2017). In our experiment, however, the microbial density was merely $10^{6} \mathrm{CFU} / \mathrm{L}$ under the plateau environmental factors. 


\section{Discussion of DO}

Large numbers of DOs come to the anoxic unit through International recirculation flow and destroyed the hypoxic environment, affecting the nitrogen removal (Li et al., 2012). With respect to total nitrogen removal, nitritation-denitritation at low DO levels of $0.3-0.5 \mathrm{mg} / \mathrm{L}$ was essentially equal to the complete nitrification- denitrification at DO levels of $1.5-2.5 \mathrm{mg} / \mathrm{L}$ with the addition of external carbon sources (Zeng et al., 2010). Under the conditions of $11 \mathrm{~h} \mathrm{HRT}, 1.0-2.0 \mathrm{mg} / \mathrm{L}$ DO concentration, 200\% mixture reflux proportion, $80 \%$ sludge reflux proportion and $20 \mathrm{~d}$ sludge age, the effluent concentration can achieve the first order A standard of Discharge Standard of Pollutants for Municipal Wastewater Treatment Plant (Zhang et al., 2011). Controlling to $\mathrm{DO}$ at $0.8-1.5 \mathrm{mg} / \mathrm{L}$, the treatment efficiency of full-scale Biolak $/ \mathrm{A}^{2} \mathrm{O}$ process was near optimal with the total nitrogen efficiency of $69.45 \%$ (Ju et al., 2013). DO levels in the range of 0.5 to $3.5 \mathrm{mg} / \mathrm{L}$ in the aeration basin did not have significant impact on effluent ortho-P concentration in a completely mixed basin within the EBPR process (Gu et al., 2006). In our experiment, the optimal DO is determined as $3.0 \mathrm{mg} / \mathrm{L}$ based on the removal rates and microorganism response. This conclusion deviates greatly from the results of the previous studies. A possible cause for the deviation lies in the unique environmental factors of the plateau.

\section{Discussion of temperature}

The temperature and functions of $\mathrm{A} 2 \mathrm{O}$ process were closely related (Zhao et al., 2010). Under the condition of average temperature of $14.2^{\circ} \mathrm{C}$ and carbon-to-nitrogen radio of 4.81, enhanced nitrogen and phosphorus removal was achieved (Wang, 2010). The changes of temperature could affect the community structure and the Shannon diversity index of nitrifying bacteria (Tao et al., 2009). In our experiment, the optimal water temperature was determined as $15^{\circ} \mathrm{C}$ based on the removal rates and microorganism response. This conclusion was very inconsistent with the results of the previous studies, which may be ascribed to the unique properties of microorganisms at low temperatures on the plateau. Because Nitrification rates at high altitude aquatic ecosystems are scarce (Hayden and Beman, 2014; Molina et al., 2018).

\section{Conclusions}

Under the unique environmental factors of plateau, this paper designs a pilot-scale A2O device to explore the effects of DO, HRT and water temperature on the removal rates of COD, TP, TN and $\mathrm{NH}_{4}{ }^{+}-\mathrm{N}$, and the law of microbial response to these working parameters. The results show that none of the TP, $\mathrm{TN}$ or $\mathrm{NH}_{4}{ }^{+}-\mathrm{N}$ of the outlet water satisfied the Chinese national standard GB18918-2002, while the COD only fulfilled the standard requirements under a few working parameters. The optimal values of the four working parameters were determined as: the optimal HRT $=26.25 \mathrm{~h}$, the optimal $\mathrm{DO}=3.0 \mathrm{mg} / \mathrm{L}$, the optimal temperature $=15^{\circ} \mathrm{C}$. All these optimal values deviated greatly from the existing studies. The microbial densities corresponded poorly to the three working parameters, and differed significantly from those under normal conditions; the number of indicator microorganisms was basically consistent with the optimal values of our experimental parameters. In addition, the SV30 (Xu et al., 2013) and NLSS (Zhang et al., 2018) were both low in our experiment. 
Acknowledgements. This work was supported by the National Natural Science Foundation of China (NO.51868069, 51769034), Natural Science Foundation of Tibet (NO. XZ 2018 ZR G-20), the Program for Scientific Research Innovation Team in Colleges and Universities of Tibet Autonomous Region, Snowy Plateaus of Tibet Agriculture and Animal Husbandry College (Study on the operation status of typical sewage treatment plants in Tibet in China).

\section{REFERENCES}

[1] Abourabia, A. M., Abdel Moneim, S. A. (2019): Analytical solution of sea water steady magneto-hydrodynamic equations subjected to stretching sheet under induced magnetic field and heat transfer. - Mathematical Modelling of Engineering Problems 6(1): 141-151.

[2] Ai, S. S., Zhang, X. H., Xiao, Y. B. (2014): Study on characteristics of activated sludge at low temperature. - Applied Mechanics \& Materials 675-677: 574-577.

[3] Chen, X. Y., Hao, Ka. Y., Su, D. (2018): Characteristic study on wastewater treatment in high altitude area by A2/O process. - Technology of Water Treatment 38(6): 93-96.

[4] Gu, A. Z., Hughes, T., Fisher, D. (2006): The devil is in the details: full-scale optimization of the EBPR process at the city of las vegas WPCF. - Proceedings of the Water Environment Federation 2006(7): 5110-5130.

[5] Hayden, C. J., Beman, M. (2014): High abundances of potentially active ammoniaoxidizing bacteria and archaea in oligotrophic, high-altitude lakes of the sierra nevada, California, USA. - Plos One 9(11): e111560.

[6] He, J. G., Ke, L., Han, B. P. (2010): Study on the operational characteristics of hybrid A2/O process at low temperature. - Applied Mechanics \& Materials 39: 326-331.

[7] Ju, Y. K., Wang, H. L., Zhang, Q. (2013): Effect of dissolved oxygen on nitrogen and phosphorus removal rate in biolak process. - Advanced Materials Research 779-780: 1629-1633.

[8] Li, Y. F., Yang, J. Y., Zhang, G. C. (2012): Effects of Aeration on Nitrogen and Phosphate Removal with A2O Process. - Advanced Materials Research 622-623: 17381741.

[9] Li, Y. F., Yang, J. Y., Zhang, G. C. (2013): Effects of aeration on nitrogen and phosphate removal with A2O process. - Advanced Materials Research 622-623: 1738-1741.

[10] Li, S. M., Du, G. S., Tang, F. B. (2013): Nitrogen and phosphorus removal of modified A2/O process on low-carbon domestic sewage under low temperature. - Advanced Materials Research 777: 187-191.

[11] Li, S. M., Hao, T., Wang, R. B. (2014): Operation of modified A 2/O process at low temperature and different sludge loadings. - China Water \& Wastewater 2014(13): 64-68.

[12] Molina, V., Dorador, C., Fernández, C. (2018): The activity of nitrifying microorganisms in a high altitude Andean wetland. - FEMS Microbiology Ecology 94(6).

[13] Ruiz-Urbieta, M., Sparrow, E. M., Parikh, P. D. (1975): Two-film reflection polarizers: theory and application. - Applied Optics 14(2): 486-492.

[14] Tao, F., Huang, Y., Gao, S., Huang, M. S., Chen, C. (2009): Application of PCR-DGGE to analyze the effect of temperatureon structure of nitrifying bacteria in $\mathrm{A} / \mathrm{O}$ system (Chinese). - Journal of East China Normal University.

[15] Tian, X., Ai, S. S., Zuo, Y. (2013): Study on activated sludge microorganisms of northern winter sewage treatment plant. - Applied Mechanics and Materials 361-363: 1032-1035.

[16] Wang, J. H. (2010): Biological nutrients removal from domestic wastewater with low carbon-to-nitrogen ratio in A 2O-BAF system at low temperature. - China Environmental Science 30(9): 1195-1200.

[17] Wang, W., Chen, S., Bao, K. (2014): Enhanced removal of contaminant using the biological film, anoxic-anaerobic-aerobic and electro-coagulation process applied to highload sewage treatment. - Environmental Technology 35(7): 833-840. 
[18] Wu, C., Guo, L. (2017): Influence of temperature and dissolved oxygen on nitrogen and phosphorus removal of integrated bioreactor. - International Journal Bioautomation 21(1): 207-216.

[19] Xu, X. P., Tao, X. W., Du, J., Wu, F. S. (2013): Effect of SRT on nitrogen and phosphorus removal in A2/O process. - China Water \& Wastewater 29(21): 69-71.

[20] Yang, T. (2017): Study on degradation Regularity of three characteristic pollutants of pharmaceutical park tail water in a2o treatment process. - Liaoning University.

[21] Ye, C., Zhou, Z., Li, M. (2018): Evaluation of simultaneous organic matters and nutrients removal from municipal wastewater using a novel bioreactor (D-A2O) system. - Journal of Environmental Management 218: 509-515.

[22] Zeng, W., Li, L., Yang, Y. (2010): Nitritation and denitritation of domestic wastewater using a continuous anaerobic-anoxic-aerobic (A2O) process at ambient temperatures. Bioresource Technology 101(21): 8074-8082.

[23] Zhang, S. R., Zhang, T. J., Liu, J. L. (2011): Study on A2O Method for co-treatment of landfill leachate and municipal sewage. - Advanced Materials Research 356-360: 29082913.

[24] Zhang, L., Zhuang, Y., Wang, X., Zhang, H. (2016): Effect of temperature on denitrifying phosphorus removal efficiency using modified A2/O process. - Transactions of the Chinese Society of Agricultural Engineering.

[25] Zhang, J. X., Sun, W. G., Niu, F. S., Wang, L., Zhao, Y. W., Han, M. M. (2018): Atmospheric sulfuric acid leaching thermodynamics from metallurgical zinc-bearing dust sludge. - International Journal of Heat and Technology 36(1): 229-236.

[26] Zhao, F., Dai, X. C., Huang, M. S. (2010): Influence of temperature on nitrogen removal in A2/O process. - Environmental Science \& Technology 33(3): 49-53.

[27] Zong, Y. C., Zhang, Y. H., Lu, G. H. (2018): Study on Process Characteristics of High Altitude A2/O Process Based on Principal Component Analysis. - Technology of water treatment 38(9): 116-119. 